\section{'Santaclara' Strawberry}

Pedro Domínguez, Juan J. Medina, José M. López-Aranda, María T. Ariza, Luis Miranda, Iraida Amaya, José F. Sánchez-Sevilla, Rosalía Villalba, and Carmen Soria ${ }^{1}$

Instituto Andaluz de Investigación y Formación Agraria y Pesquera (IFAPA), Consejería de Agricultura y Pesca, Junta de Andalucía, Avda. Isaac Newton $n^{\circ}$ 3, $2^{a}$ planta, Parque Tecnológico Cartuja'93, 41092, Seville, Spain

Additional index words. Fragaria $\times$ ananassa, fruit breeding, cultivar
Since 2000, the high significance of strawberry (Fragaria $\times$ ananassa Duch.) production in Huelva, located on the southwest coast of Spain, has led public and private institutions to increase the releasing of new cultivars that are well adapted to the climate characteristics and growing conditions in Huelva and other mild areas. The Spanish public breeding program has contributed to this effort with cultivars such as 'Andana', 'Carisma', 'Marina', 'Medina', 'Aguedilla', and 'Fuentepina' (Bartual et al., 1997, 2002; López-Aranda et al., 2004, 2005a, 2005b; Soria et al., 2010).

'Santaclara' is a new short-day cultivar recently released by the Spanish public breeding program, participating in the Spanish National Agricultural Research Institute (INIA), the Andalusian Institute of Agriculture and Fishery Research and Training (IFAPA) as well as S.A. (FNM), Freshuelva Viveristas (FV), and Nuevas Técnicas de Fresa S.L. (NTF). The main purpose of this program is to breed cultivars for high yield, large fruit size for the fresh market, and high fruit quality and which outperform currently grown shortday cultivars in mild climate areas (e.g.,

'Santaclara' is noted for its medium- to high-balanced agronomic, postharvest, and fruit quality traits (including nutraceutic values). 'Santaclara' also shows excellent comparative qualities for the fresh market and adapts well to mild agroenvironments.

This new cultivar was named after an old monastery founded in 1337 and located at Moguer (Huelva), place of birth of the 1965 Nobel prize awarded poet Juan Ramón Jiménez, who spent his youth in the strawberry production area around this nice village.

\section{Origin}

'Santaclara' was selected from a 2004 cross between the breeding line 1084-1 ('Carisma' $\times$ 'Plasirfre') and 'Ventana'; this cross (Fig. 1)

Received for publication 2 Apr. 2012. Accepted for

We thank the Agreement IFAPA/INIA of 8 July 2010 (CME10-46) and FEDER funds (European Union) for financial support and the INIA project RFP2008-00009.

${ }^{1}$ To whom reprint requests should be addressed; e-mail maria.soria@juntadeandalucia.es. the private partners Fresas Nuevos Materiales 'Camarosa'). publication 8 May 2012. was made at IFAPA (Churriana, Málaga) and was tested as selection 2340-1 in 2005 at the IFAPA production field (Moguer, Huelva). The female parent $1084-1$ is a short-day cultivar with excellent fruit appearance identified in previous field tests. 'Ventana' (Larson and Shaw, 2001) is a short-day accession chosen as the male parent as a result of its high precocity and total yield production with large to very large firm fruits. Both parents are very Huelva.

From 2005, 'Santaclara' was propagated every season for performance evaluations at high-elevation nurseries in northeastern Spain (Castilla-Leon; Arevalo-Avila, altitude 900 to $1100 \mathrm{~m}$ ). Runner-propagated plants were evaluated from 2006 to 2010 , along with other well-adapted cultivars, in replicated plot trials in an experimental field near the area of Moguer (Huelva).

\section{Description}

'Santaclara' is described subsequently following the International Union for the Protection of New Varieties of Plants (UPOV) well adapted to the growing conditions of guidelines (UPOV, 1995), and differences with 'Camarosa', when exist, are shown.

'Santaclara' is a short-day strawberry cultivar. Plant vigor is medium with a globose growth habit. When planted in high-elevation nurseries in mid-April, plants tend to produce oration and medium pubescence. Leaves are strongly to slightly concave and medium blistering with three dark green mediumglossy leaflets,; in contrast to the weak blistering, medium green leaflets of 'Camarosa'. The terminal leaflet is longer than wide with an obtuse base and crenate margins, whereas the terminal leaflet of 'Camarosa' is as long as wide.

Inflorescences are located at the end of long peduncles and flowers open at the level of the canopy. Flower size is medium and the calyx diameter is higher than the corolla. The corolla has five overlapping white petals that are broader than longer in contrast to ing petals. The conical berries are large, much longer than broader (Fig. 2), with medium red flesh and external color. The internal cavity is either small or medium expressed. The fruit surface is even, achenes are inserted leveled with the surface, and the band without achenes is absent or very narrow; 'Camarosa' fruit surface is darker and slightly uneven with achenes inserted below the surface. The calyx of 'Santaclara' is firmly attached to the fruit with a slightly larger diameter. The fruit flesh

Early and total yields for 'Santaclara' are similar to those of standard cultivars grown in southwestern Spain such as 'Camarosa' and 'Sabrosa' (Table 1). Post-harvest tests showed that 'Santaclara' has a good shelf life, similar to that of 'Camarosa' and 'Sabrosa' and longer than that of 'Aguedilla' and 'Ventana' (Table 3). The best atributtes of 'Santaclara' many runners with very low anthocyanin col'Camarosa' that shows as long as broad touchis very firm, pleasantly aromatic, and tasty.

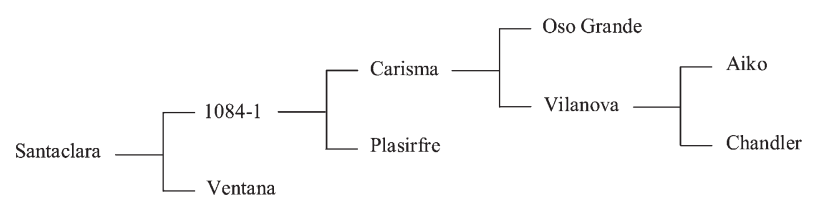

Fig. 1. Pedigree of 'Santaclara' strawberry.

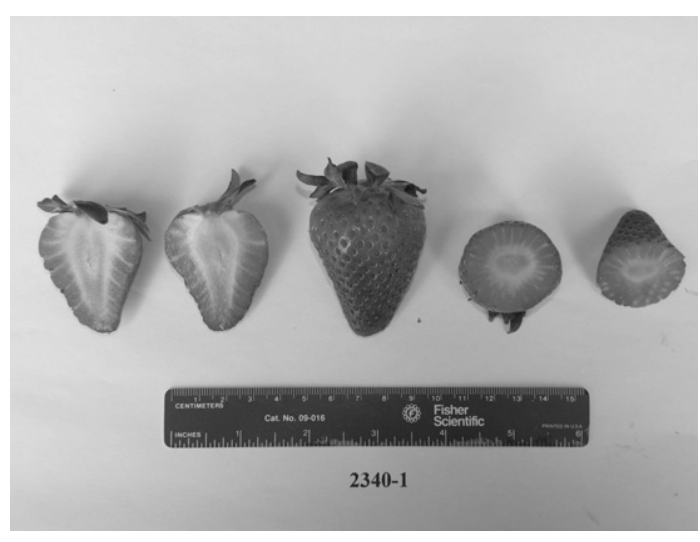

Fig. 2. Fruits of 'Santaclara' strawberry. 
are its remarkably high fruit firmness and a very high ascorbic acid content (vitamin $\mathrm{C}$ ) (Table 4).

Genetic characterization of 'Santaclara' (Gil-Ariza et al., 2006) using three microsatellites yielded the following patterns: ChFaM001: 244, 231, 212; ChFaM002: 174, 164; and ChFaM004: 187, 173, 147, 145, 137.

Table 1. Fruit yield of 'Santaclara' versus standard strawberry cultivars grown at Huelva (Spain) during 2008, 2009, and 2010 seasons.

\begin{tabular}{|c|c|c|c|c|c|}
\hline \multirow[b]{2}{*}{ Cultivar } & \multicolumn{2}{|c|}{ Early yield $^{z}$} & \multicolumn{2}{|c|}{ Total yield } & \multirow[b]{2}{*}{$\begin{array}{l}\text { Fruit wt } \\
\text { (g/fruit) }\end{array}$} \\
\hline & $\begin{array}{l}\text { Marketable } \\
\text { (g/plant) }\end{array}$ & $\begin{array}{c}\text { Second quality } \\
(\%)\end{array}$ & $\begin{array}{c}\text { Marketable } \\
\text { (g/plant) }\end{array}$ & $\begin{array}{c}\text { Second quality } \\
(\%)\end{array}$ & \\
\hline \multicolumn{6}{|l|}{2008} \\
\hline Santaclara & $585 \mathrm{ab}^{\mathrm{y}}$ & $9.5 \mathrm{~b}$ & $1007 \mathrm{~b}$ & $11.6 \mathrm{~b}$ & $26.0 \mathrm{bc}$ \\
\hline Camarosa & $528 \mathrm{bc}$ & $15.4 \mathrm{a}$ & $996 \mathrm{~b}$ & $17.1 \mathrm{a}$ & $25.1 \mathrm{c}$ \\
\hline Ventana & $632 \mathrm{a}$ & $6.3 \mathrm{c}$ & $1079 \mathrm{ab}$ & $11.3 \mathrm{~b}$ & $25.4 \mathrm{bc}$ \\
\hline Aguedilla & $624 \mathrm{a}$ & $4.3 \mathrm{~d}$ & $1163 \mathrm{a}$ & $9.1 \mathrm{bc}$ & $31.7 \mathrm{a}$ \\
\hline Amiga & $446 \mathrm{~cd}$ & $1.9 \mathrm{e}$ & $1072 \mathrm{ab}$ & $8.1 \mathrm{c}$ & $27.7 \mathrm{~b}$ \\
\hline Fuentepina & $427 \mathrm{~d}$ & $6.7 \mathrm{c}$ & $728 \mathrm{c}$ & $7.6 \mathrm{c}$ & $25.5 \mathrm{bc}$ \\
\hline \multicolumn{6}{|l|}{2009} \\
\hline Santaclara & $340 \mathrm{ab}$ & $10.4 \mathrm{ab}$ & $781 \mathrm{a}$ & $11.7 \mathrm{~b}$ & $25.8 \mathrm{c}$ \\
\hline Camarosa & $387 \mathrm{a}$ & $12.8 \mathrm{a}$ & $832 \mathrm{a}$ & $17.1 \mathrm{a}$ & $26.7 \mathrm{c}$ \\
\hline Sabrosa & $239 \mathrm{c}$ & $5.9 \mathrm{bc}$ & $717 \mathrm{ab}$ & $12.2 \mathrm{~b}$ & $25.0 \mathrm{c}$ \\
\hline Aguedilla & $384 \mathrm{a}$ & $6.4 \mathrm{bc}$ & $882 \mathrm{a}$ & $11.6 \mathrm{~b}$ & $32.1 \mathrm{a}$ \\
\hline Fuentepina & $266 \mathrm{bc}$ & $3.4 \mathrm{c}$ & $563 \mathrm{~b}$ & $6.2 \mathrm{c}$ & $29.1 \mathrm{~b}$ \\
\hline \multicolumn{6}{|l|}{2010} \\
\hline Santaclara & $289 \mathrm{bc}$ & $9.8 \mathrm{abc}$ & $831 \mathrm{~b}$ & $10.6 \mathrm{~b}$ & $24.4 \mathrm{c}$ \\
\hline Camarosa & $269 \mathrm{c}$ & $11.0 \mathrm{a}$ & $807 \mathrm{~b}$ & $14.2 \mathrm{a}$ & $25.7 \mathrm{bc}$ \\
\hline Sabrosa & $288 \mathrm{bc}$ & $6.1 \mathrm{de}$ & $803 \mathrm{bc}$ & $11.6 \mathrm{~b}$ & $25.0 \mathrm{bc}$ \\
\hline Splendor & $341 \mathrm{a}$ & $8.3 \mathrm{bc}$ & $912 \mathrm{a}$ & $11.5 \mathrm{~b}$ & $26.7 \mathrm{ab}$ \\
\hline F. Fortuna & $287 \mathrm{bc}$ & $8.1 \mathrm{~cd}$ & $689 \mathrm{~d}$ & $9.6 \mathrm{~b}$ & $25.3 \mathrm{bc}$ \\
\hline Primoris & $310 \mathrm{ab}$ & $10.0 \mathrm{ab}$ & $866 \mathrm{ab}$ & $14.4 \mathrm{a}$ & $24.2 \mathrm{c}$ \\
\hline Antilla & $261 \mathrm{c}$ & $3.5 \mathrm{f}$ & $708 \mathrm{~d}$ & $7.1 \mathrm{c}$ & $28.4 \mathrm{a}$ \\
\hline Fuentepina & $314 \mathrm{ab}$ & $4.2 \mathrm{ef}$ & $735 \mathrm{~cd}$ & $5.6 \mathrm{c}$ & $25.7 \mathrm{bc}$ \\
\hline
\end{tabular}

${ }^{2}$ Early yield: up to the end of March.

${ }^{y}$ Mean values in each column followed by different letters are significantly different at $P \leq 0.05$ as determined by Fisher's least significant difference test.

Table 2. Comparison of fruit quality traits of 'Santaclara' versus standard strawberry cultivars grown at Huelva (Spain) during the 2008, 2009, and 2010 seasons.

\begin{tabular}{|c|c|c|c|c|c|}
\hline Cultivar & $\begin{array}{l}\text { External } \\
\text { color }^{2}\end{array}$ & $\begin{array}{l}\text { Internal } \\
\text { color }^{\mathrm{z}}\end{array}$ & $\begin{array}{l}\text { Internal cavity } \\
\text { size }^{\mathrm{y}}\end{array}$ & $\begin{array}{c}\text { Firmness } \\
\text { (g of pressure) }\end{array}$ & $\begin{array}{c}\text { Total sugar } \\
\text { content }\left({ }^{\circ} \text { Brix }\right)\end{array}$ \\
\hline \multicolumn{6}{|l|}{2008} \\
\hline Santaclara & $5.7 \mathrm{abc}^{\mathrm{x}}$ & $4.8 \mathrm{ab}^{\mathrm{x}}$ & $4.8 \mathrm{ab}^{\mathrm{x}}$ & $375 b^{w}$ & $7.4 c^{w}$ \\
\hline Camarosa & $6.6 \mathrm{a}$ & $5.4 \mathrm{a}$ & $5.0 \mathrm{a}$ & $357 \mathrm{c}$ & $7.9 \mathrm{~b}$ \\
\hline Ventana & $6.0 \mathrm{ab}$ & $5.0 \mathrm{a}$ & $4.1 \mathrm{ab}$ & $325 \mathrm{~d}$ & $7.1 \mathrm{~cd}$ \\
\hline Aguedilla & $6.3 \mathrm{a}$ & $5.0 \mathrm{a}$ & $5.9 \mathrm{a}$ & $313 d$ & $6.8 \mathrm{~d}$ \\
\hline Amiga & $4.9 \mathrm{bc}$ & $5.0 \mathrm{a}$ & $4.6 \mathrm{ab}$ & $443 \mathrm{a}$ & $6.7 \mathrm{~d}$ \\
\hline Fuentepina & $4.8 \mathrm{c}$ & $3.0 \mathrm{~b}$ & $3.2 \mathrm{~b}$ & $350 \mathrm{c}$ & $8.4 \mathrm{a}$ \\
\hline \multicolumn{6}{|l|}{2009} \\
\hline Santaclara & $5.9 \mathrm{~b}$ & $4.8 \mathrm{ab}$ & $3.4 \mathrm{~b}$ & $387 \mathrm{a}$ & $7.7 \mathrm{bc}$ \\
\hline Camarosa & $7.0 \mathrm{a}$ & $5.9 \mathrm{a}$ & $4.6 \mathrm{ab}$ & $347 \mathrm{c}$ & $8.1 \mathrm{ab}$ \\
\hline Sabrosa & $6.0 \mathrm{ab}$ & $5.0 \mathrm{ab}$ & $4.3 \mathrm{ab}$ & $374 \mathrm{ab}$ & $8.6 \mathrm{a}$ \\
\hline Aguedilla & $6.3 \mathrm{ab}$ & $5.9 \mathrm{a}$ & $5.2 \mathrm{a}$ & $322 \mathrm{~d}$ & $7.5 \mathrm{c}$ \\
\hline Fuentepina & $5.2 \mathrm{~b}$ & $3.9 \mathrm{~b}$ & $3.0 \mathrm{~b}$ & $364 \mathrm{bc}$ & $8.3 \mathrm{a}$ \\
\hline \multicolumn{6}{|l|}{2010} \\
\hline Santaclara & $5.8 \mathrm{ab}$ & $4.8 \mathrm{abc}$ & $3.9 \mathrm{ab}$ & $444 \mathrm{a}$ & $6.9 \mathrm{~cd}$ \\
\hline Camarosa & $6.1 \mathrm{a}$ & $6.1 \mathrm{a}$ & $4.0 \mathrm{ab}$ & $387 \mathrm{~d}$ & $6.6 \mathrm{~d}$ \\
\hline Sabrosa & $5.2 \mathrm{bc}$ & $4.9 \mathrm{abc}$ & $3.7 \mathrm{ab}$ & $412 \mathrm{c}$ & $7.3 \mathrm{abc}$ \\
\hline Splendor & $6.2 \mathrm{a}$ & $5.9 \mathrm{a}$ & $4.4 \mathrm{a}$ & $321 \mathrm{e}$ & $5.9 \mathrm{e}$ \\
\hline F. Fortuna & $5.7 \mathrm{ab}$ & $5.3 \mathrm{ab}$ & $3.2 \mathrm{~b}$ & $374 d$ & $6.9 \mathrm{bcd}$ \\
\hline Primoris & $4.7 \mathrm{c}$ & $4.9 \mathrm{abc}$ & $3.2 \mathrm{~b}$ & $440 \mathrm{ab}$ & $7.7 \mathrm{a}$ \\
\hline Antilla & $5.4 \mathrm{abc}$ & $4.0 \mathrm{bc}$ & $3.8 \mathrm{ab}$ & $430 \mathrm{~b}$ & $7.4 \mathrm{ab}$ \\
\hline Fuentepina & $4.4 \mathrm{c}$ & $3.7 \mathrm{c}$ & $3.1 \mathrm{~b}$ & $386 \mathrm{~d}$ & $6.7 \mathrm{~d}$ \\
\hline
\end{tabular}

${ }^{\mathrm{z}}$ Rated on a scale from 3 to 7 , where $3=$ light red and $7=$ deep red.

${ }^{\mathrm{y}}$ Rated on a scale from 3 to 7 , where $3=$ absent and $7=$ large internal cavity along the fruit.

${ }^{\mathrm{x}}$ Within columns, mean values followed by different letters are significantly different at $P \leq 0.05$ as determined by the Kruskal-Wallis comparison test.

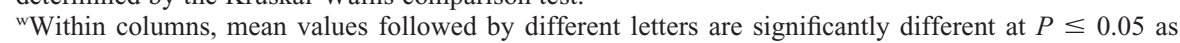
determined by Fisher's least significant difference test.
'Sabrosa', 'Splendor', 'Florida Fortuna' (named 'Florida Radiance' in USA), 'Primoris', and 'Antilla'. Throughout those 3 years, cultivar performance was evaluated in experimental fields in the strawberry production area of Moguer (Huelva).

To reduce the presence of soilborne pathogens, an experimental plot soil was solarized and biofumigated each year (Medina et al., 2009) before planting.

During the third week of October of each year (2008, 2009, and 2010), plants were planted in three completely randomized plots of 50 plants each on two-row raised beds covered with black plastic and drip irrigation pipes under the plastic. Plants were spaced $0.25 \times 0.25 \mathrm{~m}$ apart. In mid-November plants were covered with large plastic $(150 \mu \mathrm{m})$ tunnels $(6.6 \mathrm{~m}$ wide $\times 3.5 \mathrm{~m}$ high $\times 70 \mathrm{~m}$ long). Between mid-November and midMay, the fertilizer rate was: $175 \mathrm{~kg} \mathrm{~N} / \mathrm{ha}$, $77 \mathrm{~kg} \mathrm{P}_{2} \mathrm{O}_{5} / \mathrm{ha}, 185 \mathrm{~kg} \mathrm{~K}_{2} \mathrm{O} / \mathrm{ha}, 85 \mathrm{~kg} \mathrm{CaO} / \mathrm{ha}$, and $14 \mathrm{~kg} \mathrm{MgO} / \mathrm{ha}$. Marketable fruits (firstplus second-quality fruits; no misshapen fruits of $17 \mathrm{~g}$ or greater and between 10 and $17 \mathrm{~g}$, respectively) were harvested and weighed once or twice a week from early January to late May.

Fruit weight was calculated by weighing 20 first-quality fruits eight times throughout the season and dividing total weight by the number of harvested fruits (160). Three times per season (mid-February, mid-March, and mid-May), six randomly chosen fruits per plot were evaluated for quality traits such as external and internal color, internal cavity size, firmness, and soluble solid content and

Table 3. Shelf life parameters of 'Santaclara' and other strawberry cultivars grown in Huelva, Spain, during the 2008, 2009, and 2010 crop seasons.

\begin{tabular}{lll}
\hline Cultivar & Calyx freshness $^{z}$ & Bruising $^{y}$ \\
\hline 2008 & & \\
Santaclara & $5.2 \mathrm{ab}^{\mathrm{x}}$ & $6.2 \mathrm{ab}$ \\
Camarosa & $5.2 \mathrm{ab}$ & $5.8 \mathrm{abc}$ \\
Ventana & $4.0 \mathrm{~b}$ & $4.7 \mathrm{bc}$ \\
Aguedilla & $4.7 \mathrm{ab}$ & $4.3 \mathrm{c}$ \\
Amiga & $4.5 \mathrm{~b}$ & $7.0 \mathrm{a}$ \\
Fuentepina & $6.2 \mathrm{a}$ & $6.7 \mathrm{a}$ \\
2009 & & \\
Santaclara & $6.0 \mathrm{a}$ & $5.0 \mathrm{ab}$ \\
Camarosa & $6.7 \mathrm{a}$ & $5.3 \mathrm{ab}$ \\
Sabrosa & $6.7 \mathrm{a}$ & $6.3 \mathrm{a}$ \\
Aguedilla & $5.2 \mathrm{a}$ & $3.7 \mathrm{~b}$ \\
Fuentepina & $6.3 \mathrm{a}$ & $5.5 \mathrm{a}$ \\
2010 & & \\
Santaclara & $4.8 \mathrm{abc}$ & $6.0 \mathrm{a}$ \\
Camarosa & $4.4 \mathrm{bc}$ & $6.0 \mathrm{a}$ \\
Sabrosa & $5.1 \mathrm{abc}$ & $6.3 \mathrm{a}$ \\
Splendor & $5.5 \mathrm{ab}$ & $5.8 \mathrm{a}$ \\
F. Fortuna & $3.8 \mathrm{c}$ & $6.1 \mathrm{a}$ \\
Primoris & $5.8 \mathrm{a}$ & $6.8 \mathrm{a}$ \\
Antilla & $5.7 \mathrm{ab}$ & $6.7 \mathrm{a}$ \\
Fuentepina & $5.3 \mathrm{ab}$ & $5.9 \mathrm{a}$ \\
\hline
\end{tabular}

${ }^{2}$ Rated on a scale from 3 to 7 , where $3=$ low calyx freshness and $7=$ high calyx freshness.

${ }^{\mathrm{y}}$ Rated on a scale from 3 to 7 , where 3 = highly bruised and $7=$ not bruised.

${ }^{\mathrm{x}}$ Within columns, mean values followed by different letters are significantly different at $P \leq 0.05$ as determined by the Kruskal-Wallis comparison test. 
only twice (mid-February and mid-May) for acidity. Color and cavity size were subjectively rated on a visual scale (Table 2). Fruit firmness was determined using a penetrometer with a $3.5-\mathrm{mm}$ tip, soluble solid content was measured using a refractometer (Domínguez et al., 2004), and acidity by an automatic titration unit; results were expressed as grams citric acid per $100 \mathrm{~g}$ of fresh weight. To estimate the shelf life of 'Santaclara' fruits and compare it with the other cultivars, three times during the season, $500 \mathrm{~g}$ of randomly chosen ripe fruits per plot were maintained under controlled temperature $\left(4{ }^{\circ} \mathrm{C}\right)$ in a refrigerated chamber during $3 \mathrm{~d}$ followed by $2 \mathrm{~d}$ at room temperature; then calyx freshness and resistance to bruising were evaluated. Each trait was rated on a scale from 3 to 7 , in which 3 is low calyx freshness and high bruising and 7 is high calyx freshness and not bruising (Table 3).

During the 2009 season, nutraceutic traits (Table 4) on 'Santaclara' fruits were compared with those of 'Camarosa', 'Aguedilla', 'Fuentepina', and 'Sabrosa'. For the determination of nutraceutic compounds content, two assessments were run along the growing season: in mid-February and mid-April. Each time, a 250-g sample of randomly chosen ripe fruit per replication and plot was homogenized and stored at $-20{ }^{\circ} \mathrm{C}$. Total soluble phenolic compounds were measured in frozen samples using the Folin-Ciocalteu reagent (Slinkard and Singleton, 1977) and expressed as milligrams of galic acid equivalent (GAE) per $100 \mathrm{~g}$ fresh weight. Total flavonoid content was measured by the aluminium chloride colorimetric assay (Dewanto et al., 2002) and expressed as milligrams of catechin equivalent (CE) per $100 \mathrm{~g}$ fresh weight. Total anthocyanins were determined following the procedure of Cheng and Breen (1991) and expressed as milligrams of pelargonidin-3 glucoside equivalent (Pg-3-gluc) per $100 \mathrm{~g}$ fresh weight. Total ascorbic acid was measured with reflectometric test strips (Reflectoquant; Merck, Darmstadt, Germany) and expressed as milligrams per $100 \mathrm{~g}$ fresh weight.

A variance analysis was applied to the recorded data using Statistix 8.0 software (Analytical Software, Tallahassee, FL) and mean values were compared at the 0.05 level using Fisher's least significant difference test or the Kruskal-Wallis test (for subjective data).
The percentage of second-quality fruit was arcsine-transformed before analysis.

Results for 'Santaclara' yield, fruit quality, and shelf life traits are provided in Tables 1, 2, and 3. Early and total fruit yields of 'Santaclara' were similar to those of 'Camarosa' and 'Sabrosa' in the three growing seasons; however, 'Camarosa' produced a higher early and total percentage of second-quality fruit in most years (Table 1). 'Aguedilla' in 2008 and 'Splendor' in 2010 produced higher yields than 'Santaclara'. In general, early and total percentage of second-quality fruit of 'Santaclara' is intermediate (ranging between $9 \%$ and $12 \%$ of marketable production). The average fruit size of 'Santaclara' was significantly smaller than 'Aguedilla' fruits in 2008 and 2009 and than 'Antilla' fruits in 2010 but was similar to that of the other cultivars, ranging between 24.4 and $26.0 \mathrm{~g}$.

Overall, higher values of yield (early and total yield) were obtained in 2008, which could be related to the optimal meteorological conditions recorded during that year in contrast to the low temperatures of 2009 and the excessive rainfall of 2010 (IFAPA, 2011).

The color of fully mature 'Santaclara' fruits was intermediate red both on the outside and the inside (Table 2). External color of 'Aguedilla', 'Ventana', 'Camarosa', and 'Splendor' was darker and 'Amiga', 'Fuentepina', and 'Primoris' was lighter than 'Santaclara' fruits.

The internal cavity was weakly to medium expressed and, in general, similar to that recorded for the other cultivars. 'Santaclara' fruit firmness ranged from 375 to $444 \mathrm{~g}$ pressure, values higher than those recorded for the majority of cultivars. Only 'Amiga' (443 g pressure in 2008) showed higher firmness than 'Santaclara'. Fruits of 'Santaclara' are tasteful and their soluble solid content ranged from 6.9 to $7.7^{\circ} \mathrm{Brix}$; these values were similar to those of 'Camarosa' and 'Florida Fortuna' but lower than those of 'Fuentepina', 'Sabrosa', 'Primoris', and 'Antilla' and significantly higher than those of 'Aguedilla', 'Amiga', and 'Splendor' (Table 2).

'Santaclara' fruits showed good shelf life. Calyx freshness and resistance to bruising were similar to that of 'Camarosa', 'Amiga', 'Fuentepina', 'Sabrosa', 'Splendor', 'Primoris', and 'Antilla' fruits but higher than that of
'Aguedilla', 'Ventana', and 'Florida Fortuna' fruits (Table 3 ).

During the 2009 season, nutraceutic traits (Table 4) for 'Santaclara' fruits were assessed and compared with values of 'Camarosa', 'Sabrosa', 'Aguedilla', and 'Fuentepina' fruits. Total phenolic content of 'Santaclara' fruits was $110 \mathrm{mg}$ GAE per $100 \mathrm{~g}$ fresh weight, similar to those recorded for the other cultivars. Total anthocyanin content reached $13.5 \mathrm{mg}$ Pg-3-gluc per $100 \mathrm{~g}$ fresh weight, which was similar to that of 'Camarosa' and 'Aguedilla' and higher than that of 'Sabrosa' and 'Fuentepina'. 'Santaclara' fruits showed the lowest flavonoid content with $8.8 \mathrm{mg} \mathrm{CE}$ per $100 \mathrm{~g}$ fresh weight. However, it is very important to point out that 'Santaclara' fruits had higher ascorbic acid content, $59.7 \mathrm{mg}$ per $100 \mathrm{~g}$ fresh weight, significantly higher than any of the other tested cultivars.

Plants of 'Santaclara' and 'Camarosa' were inoculated artificially in the laboratory with Xanthomonas fragariae Kennedy \& King, Phythophthora cactorum (Lebert \& Cohn), Verticillium dahliae Kleb., and Podosphaera aphanis (Wallr.); the latter was also evaluated under field conditions. The resistance of 'Santaclara' to $X$. fragariae was greater than that observed for 'Camarosa; the resistance to $P$. cactorum was similar; however, resistance to $P$. aphanis and $V$. dahliae was less than that of 'Camarosa' (De Cal, personal communication).

As a summary, the strengths of this new cultivar are its balanced agronomic and nutraceutic characteristics such as high early and total yields, large fruits and high fruit firmness, low percentage of misshapen fruits, and high ascorbic acid content. On the other hand, the weakness of 'Santaclara' is a medium to high percentage of second-class fruits (Table 1), mainly in early plantings.

\section{Availability}

The Andalusian Government (IFAPAJunta de Andalucía), INIA, FNM, NTF, and FV have jointly applied for the inscription of 'Santaclara' in the Register of Commercial Strawberry Varieties (Spanish Plant Variety Office, application number 20090247).

Third parties interested in the propagation and/or commercial use of this cultivar should contact the authors of this article. E-mail: josem.lopez.aranda@juntadeandalucia.es.

\section{Literature Cited}

Table 4. Comparison of nutraceutic compounds content on 'Santaclara' fruits versus standard strawberry cultivars grown at Huelva (Spain) during the 2009 season.

\begin{tabular}{lccccc}
\hline Cultivar & Phenolics compounds $^{\mathrm{z}}$ & Flavonoids $^{\mathrm{y}}$ & Anthocyanins $^{\mathrm{x}}$ & Ascorbic acid $^{\mathrm{w}}$ & Titratable acidity $^{\mathrm{v}}$ \\
\hline Santaclara & $110.0 \mathrm{a}^{\mathrm{u}}$ & $8.8 \mathrm{~d}$ & $13.5 \mathrm{a}$ & $59.7 \mathrm{a}$ & $0.72 \mathrm{c}$ \\
Camarosa & $130.9 \mathrm{a}$ & $12.7 \mathrm{~b}$ & $15.2 \mathrm{a}$ & $47.2 \mathrm{~b}$ & $0.88 \mathrm{a}$ \\
Sabrosa & $111.2 \mathrm{a}$ & $12.5 \mathrm{~b}$ & $10.3 \mathrm{~b}$ & $48.7 \mathrm{~b}$ & $0.78 \mathrm{~b}$ \\
Aguedilla & $117.9 \mathrm{a}$ & $18.3 \mathrm{a}$ & $13.1 \mathrm{a}$ & $50.7 \mathrm{~b}$ & $0.89 \mathrm{a}$ \\
Fuentepina & $104.3 \mathrm{a}$ & $11.3 \mathrm{c}$ & $7.9 \mathrm{~b}$ & $44.8 \mathrm{~b}$ & $0.59 \mathrm{~d}$ \\
\hline
\end{tabular}

${ }^{\mathrm{z}}$ Expressed as milligrams of gallic acid equivalent $/ 100 \mathrm{~g}$ fresh fruit.

${ }^{\mathrm{y}}$ Expressed as milligrams of catechin equivalent $/ 100 \mathrm{~g}$ fresh fruit.

${ }^{x}$ Expressed as milligrams of pelargonidin-3-glucoside/100 $\mathrm{g}$ fresh fruit.

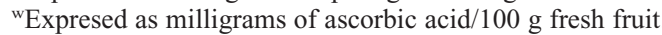

${ }^{\vee}$ Expressed as grams citric acid/100 $\mathrm{g}$ fresh weight.

${ }^{u}$ Within columns, mean values followed by different letters are significantly different at $P \leq 0.05$ as deteermined by Fisher's least significant difference test.
Bartual, R., J.M. López-Aranda, J.I. Marsal, J.J. Medina, J. López-Medina, and R. LópezMontero. 1997. Calderona: A new public Spanish strawberry cultivar. Acta Hort. 439: 261-267.

Bartual, R., J.I. Marsal, J.M. López-Aranda, J.J. Medina, R. López-Montero, A. Arjona, and J. López-Medina. 2002. Carisma: A new Spanish strawberry cultivar. Acta Hort. 567:187-189.

Cheng, G.W. and P. Breen. 1991. Activity of phenylalanina ammonia-lyase (PAL) and concentrations of anthocyanins and phenolics in developing strawberry fruit. J. Amer. Soc. Hort. Sci. 116:865-869. 
Dewanto, V., X. Wu, K.K. Adom, and R.H. Liu. 2002. Thermal processing enhances the nutritional values of tomatoes by increasing the total antioxidant activity. J. Agr. Food Chem. 50:3010-3014.

Domínguez, F., D. Borrero, J.J. Medina-Minguez, J. Regidor, and M.T. Ariza, F. Delgado, M.D. Delgado, F. Fernández, F. Flores, J. Gálvez, F.J. Garrido, J.M. López-Aranda, J. López Medina, L. Miranda, C.J. Pérez, M.D. Sánchez, C. Soria, and C. Vélez. 2004. RAEA. Fresas. Ensayo de variedades de fresa. Campaña 2004. Consejería de Agricultura y Pesca, Junta de Andalucía.

Gil-Ariza, D.J., I. Amaya, M.A. Botella, J. MuñozBlanco, J.L. Caballero, J.M. López-Aranda, V. Valpuesta, and J.F. Sánchez-Sevilla. 2006. EST-derived polymorphic microsatellites from cultivated strawberry (Fragaria $\times$ ananassa) are useful for diversity studies and varietal identification among Fragaria species. Mol. Ecol. Notes 6:1195-1197.
IFAPA. 2011. Consejería de Agricultura y pesca, Junta de Andalucía. Red Andaluza de Experimentación Agraria (RAEA). 2 May 2012. <http:/ web5.ifapa.junta-andalucia.es/agriculturaypesca/ ifapa/web/ifapa/productos/transferencia/raea $>$.

Larson, K.D. and D.V. Shaw. 2001. 'Ventana' strawberry cultivar. United States Patent Declaration No. PP13,469.

López-Aranda, J.M., C. Soria, J.F. Sánchez-Sevilla, J. Gálvez, J.J. Medina, A. Arjona, J.I. Marsal, and R. Bartual. 2004. 'Marina' strawberry. HortScience 39:1776-1777.

López-Aranda, J.M., C. Soria, J.F. Sánchez-Sevilla, J. Gálvez, J.J. Medina, A. Arjona, J.I. Marsal, and R. Bartual. 2005a. 'Medina' strawberry. HortScience 40:482-483.

López-Aranda, J.M., C. Soria, L. Miranda, J.F. Sánchez-Sevilla, J. Gálvez, R. Villalba, F. Romero, B. De Los Santos, J.J. Medina, J. Palacios, E. Bardón, A. Arjona, A. Refoyo, A. Martínez-Treceño, A. De Cal, P. Melgarejo, and R. Bartual. 2005b. 'Aguedilla' strawberry. HortScience 40:2197-2199.

Medina, J.J., L. Miranda, C. Soria, P. Palencia, and J.M. López-Aranda. 2009. Non-chemical alternatives to methyl bromide for strawberry: Biosolarization as case-study in Huelva (Spain). Acta Hort. 842:961-964.

Slinkard, K. and V.L. Singleton. 1977. Total phenol analysis: Automation and comparison with manual methods. Amer. J. Enol. Viticult. 28:49-55.

Soria, C., J.J. Medina, P. Domínguez, M.T. Ariza, L. Miranda, R. Villalba, J. Gálvez, J.F Sánchez-Sevilla, I. Amaya, R. Sesmero, and J.M. López-Aranda. 2010. 'Fuentepina' strawberry. HortScience 45:448-450.

UPOV. International union for the protection of new varieties of plants. 1995. Guidelines for the conduct of test for distinctness, uniformity and stability-Strawberry (Fragaria L.). UPOV publication TG/22/9, Geneva. 27 Oct. 2008. $<$ http://www.upov.int $>$. 